\title{
Mitigation of agricultural emissions in the tropics: comparing forest land-sparing options at the national level
}

\author{
S. Carter ${ }^{1,3}$, M. Herold ${ }^{1}$, M. C. Rufino ${ }^{2}$, K. Neumann ${ }^{1,4}$, L. Kooistra ${ }^{1}$, and L. Verchot ${ }^{3}$ \\ ${ }^{1}$ Laboratory of Geo-Information Science and Remote Sensing, Wageningen University, 6708 PB \\ Wageningen, the Netherlands \\ ${ }^{2}$ Center for International Forestry Research (CIFOR), P.O. Box 30677, 00100 Nairobi, Kenya \\ ${ }^{3}$ Center for International Forestry Research (CIFOR), Jl CIFOR, Bogor 16115, Indonesia \\ ${ }^{4}$ Environmental Research Centre (UFZ), 04318, Leipzig, Germany \\ Correspondence to: S. Carter (sarah.carter@wur.nl)
}

Received: 27 February 2015 - Published in Biogeosciences Discuss.: 10 April 2015

Revised: 22 July 2015 - Accepted: 27 July 2015 - Published: 10 August 2015

\begin{abstract}
Emissions from agriculture-driven deforestation are of global concern, but forest land-sparing interventions such as agricultural intensification and utilization of available non-forest land offer opportunities for mitigation. In many tropical countries, where agriculture is the major driver of deforestation, interventions in the agriculture sector could reduce deforestation emissions as well as reduce emissions in the agriculture sector. Our study uses a novel approach to quantify agriculture-driven deforestation and associated emissions in the tropics between 2000 and 2010. Emissions from agriculture-driven deforestation in the tropics (97 countries) are $4.3 \mathrm{GtCO}_{2} \mathrm{e} \mathrm{yr}^{-1}$. We investigate the national potential to mitigate these emissions through forest land-sparing interventions, which can potentially be implemented under REDD + . We consider intensification and utilization of available non-forested land as forest land-sparing opportunities since they avoid the expansion of agriculture into forested land. In addition, we assess the potential to reduce agricultural emissions on existing agriculture land. The use of a systematic framework demonstrates the selection of mitigation interventions by considering sequentially the level of emissions, mitigation potential of various interventions, enabling environment and associated risks to livelihoods at the national level. Our results show that considering only countries with high emissions from agriculture-driven deforestation, with potential for forest-sparing interventions and a good enabling environment (e.g. effective governance or engagement in REDD+), there is a potential to mitigate $1.3 \mathrm{GtCO}_{2} \mathrm{e} \mathrm{yr}^{-1}$ (20 countries of 78 with sufficient data). For countries where
\end{abstract}

we identify agricultural emissions as a priority for mitigation, up to $1 \mathrm{GtCO}_{2} \mathrm{e} \mathrm{yr}^{-1}$ could be reduced from the agriculture sector including livestock. Risks to livelihoods from implementing interventions based on national level data call for detailed investigation at the local level to inform decisions on mitigation interventions. Three case studies demonstrate the use of the analytical framework. The inherent link between the agriculture and forestry sectors due to competition for land suggests that these sectors cannot be considered independently. Our findings highlight the need to include the forest and the agricultural sectors in the decision-making process to mitigate deforestation.

\section{Introduction}

The agriculture and forestry sectors, including deforestation and forest degradation, are major contributors of global greenhouse gas (GHG) emissions, accounting for approximately half of low income countries' total GHG emission budgets (IPCC, 2014). Estimates suggest that global emissions from deforestation were $4.9 \pm 0.6 \mathrm{CO}_{2} \mathrm{e} \mathrm{yr}^{-1}$ in 2010 , around $8 \%$ of anthropogenic GHG emissions (Tubiello et al., 2015). According to Hosonuma et al. (2012), in 13 countries agricultural expansion is the only driver of deforestation. Natural vegetation is at a higher risk than other land cover types, and a quarter is under threat from expansion of agriculture (Creed et al., 2010). Between 1980 and 2000, $83 \%$ of agricultural expansion in the tropics occurred in forested 
land causing major environmental impacts including loss of carbon stocks and habitats (Gibbs et al., 2010). Agriculture itself has been an increasing source of emissions, growing at around $1 \%$ annually since 1990 to $5.4 \mathrm{GtCO}_{2} \mathrm{e} \mathrm{yr}^{-1}$ in 2012 (Tubiello et al., 2015).

Land-sparing interventions are supposed to increase the output on agricultural land reducing the need to increase agricultural areas promoting deforestation (Stevenson et al., 2013). Agricultural intensification which reduces the gap between potential yield and actual yield (Byerlee et al., 2014; van Ittersum et al., 2013; Neumann et al., 2010; Wilkes et al., 2013) can contribute to land sparing. The potential yield is the maximum yield given the biophysical conditions - with the absence of any limitations (Neumann et al., 2010). The agricultural yield gap can be reduced by interventions into the farming system, for example, by altering the timing or method of applying agricultural inputs, or increasing cropping frequency. Depending on the introduced change, the intervention will require one or a combination of an increase in labour, capital, technology or a methodological change. Yield gap data provide information on where feasible improvements can lead to increased production (Neumann et al., 2010). The tropics, where yields are typically lower than in temperate regions (West et al., 2010), are often characterized by a high yield gap.

Increasing agricultural production on under-utilized lands or introducing production on non-forested land provides another opportunity to spare forests. There is generally a consensus that non-utilized, non-forested land is available for agriculture although there is active debate as to the extent (Eitelberg et al., 2015). Available land includes land with potential for intensification, for example degraded grasslands or abandoned cropland.

These interventions can be potentially included in REDD+ strategies and when implemented with climate smart agriculture (CSA) principles, can reduce emissions from agriculture as well as avoiding deforestation (FAO, 2013). There is also a potential for community benefits to accompany agricultural expansion and developments, however they can also negatively affect local communities. Access to land can be compromised, and interventions may not offer equitable distribution of benefits to stakeholders, excluding vulnerable communities (Mbow, 2010).

REDD+ is a results-based financing mechanism which funds activities to reduce emissions from deforestation and forest degradation while promoting forest conservation, sustainable management of forests and enhancing carbon stocks (UNFCCC, 2013). Interventions in the agriculture sector, for example agroforestry, are considered promising options to reduce emissions under REDD+ (Grieg-Gran, 2010), and by 2012, 42 national governments considered agriculture in their REDD+ readiness strategies (Kissinger et al., 2012). However, many countries do not establish REDD+ interventions which address the drivers of deforestation, including agricultural expansion (Salvini et al., 2014).

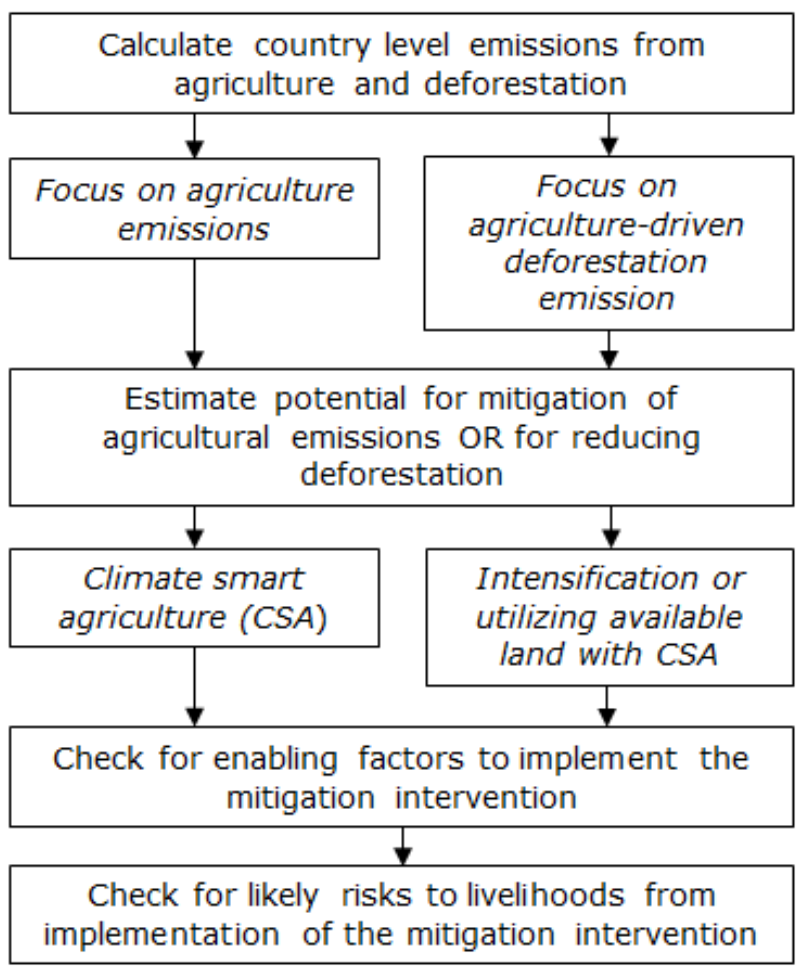

Figure 1. National-scale assessment of the need, potential and risk of implementing interventions to reduce emissions from agriculture and agricultural-driven deforestation.

To evaluate land-sparing interventions, our study systematically compares countries to show which have the largest potential to mitigate GHG emissions from agriculture-driven deforestation and from agriculture (Fig. 1). Firstly, we quantify emissions from agriculture-driven deforestation and agriculture in each country. Secondly, we pose the question whether closing the yield gap and utilizing available land could be potentially incorporated into the REDD+ context to address these emissions. In addition, we assess the potential for reducing emissions directly from existing agricultural land using CSA. We indicate countries which are likely to require increased support to implement mitigation initiatives by assessing their capacity to implement interventions. Lastly, we assess risks to livelihoods from the implementation of interventions. Mitigation pathways in three selected countries are explored in depth to illustrate the applications of this framework and to demonstrate that decisions made using the framework at the global level are relevant for the country level. 


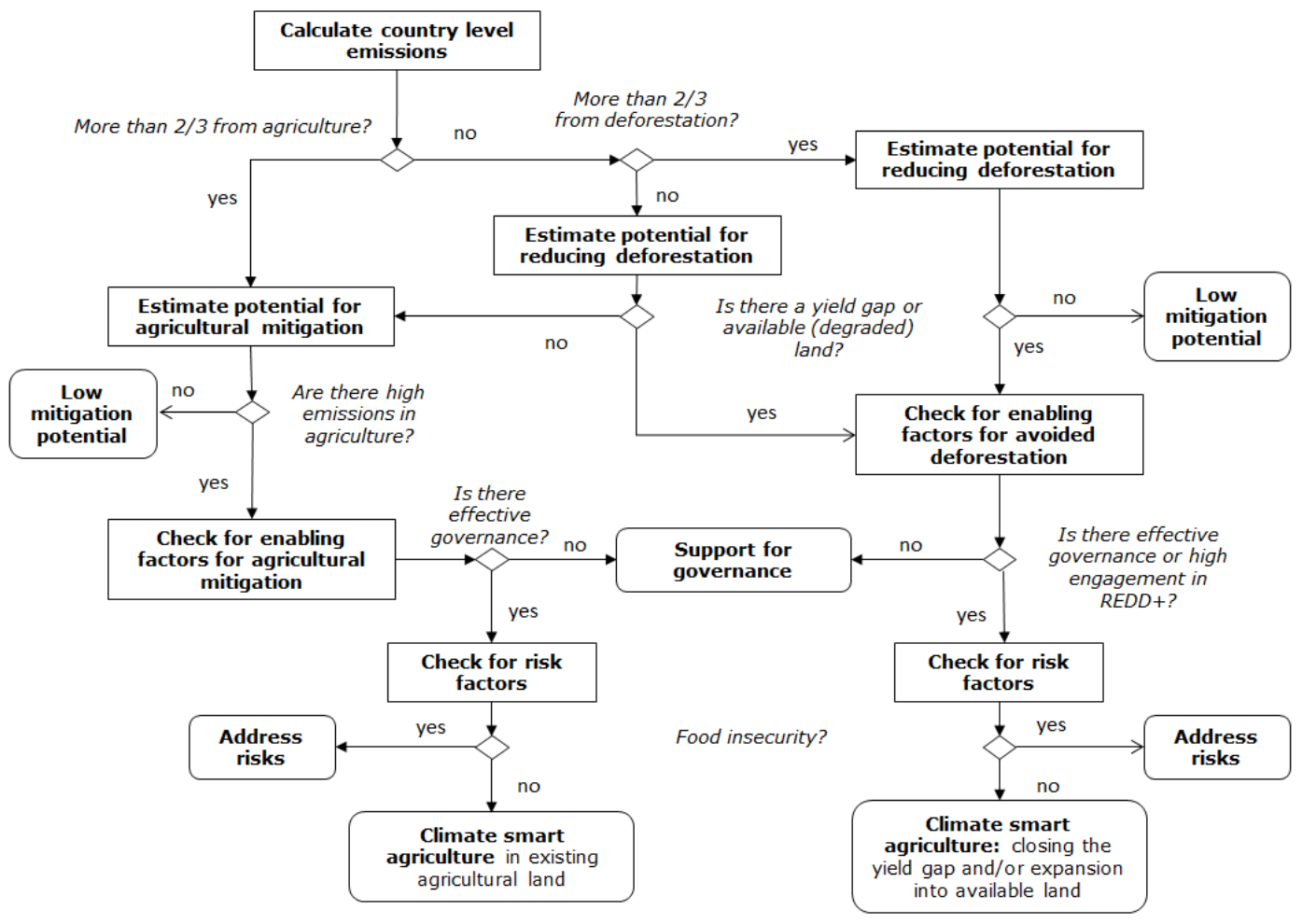

Figure 2. Decision tree to identify priority areas for mitigation interventions. Data required for decision making are described in Table 1.

\section{Data and methodology}

This study considered all tropical (within the tropics, or with a tropical biome; WWF, 2013) non-annex 1 countries or countries that are engaged in REDD + . Not all had data available to assess the mitigation potential (Fig. 1), leaving 78 countries which represent $85 \%$ of the forest area in the tropics for the study. However, 97 countries had data available to calculate emissions from agriculture-driven deforestation and of those, all but two had data on emissions from agriculture ( $n=95$ for total emissions), so these results are presented (Sect. 3.1).

We developed a framework to assess the current potential of each country to mitigate GHG emissions from agriculturedriven deforestation and agricultural activities (Fig. 2). We looked at the potential for mitigation through sparing land by (1) closing the yield gap and (2) by utilizing non-forested land suitable for agricultural activities. It is possible that synergies occur between closing the yield gap and utilizing available land that can provide benefits when both mitigation approaches are implemented within the same country. However, in this study we assume there is potential to mitigate agriculture-driven deforestation when either one of the two approaches is feasible, and we do not consider any additional mitigation benefits in countries with potential for both approaches. Where agricultural emissions are largest, we estimated the potential to mitigate these emissions. For countries with a high potential for mitigation, we assessed the potential for a mitigation intervention to be implemented successfully, by considering constraints to effective implementation (poor governance, lack of engagement in REDD+). Risks to livelihoods as a result of interventions (indicated by food insecurity) were then considered. Countries were divided into three groups using each data source, and groups were defined by dividing the data at the $1 / 3$ and $2 / 3$ rd percentiles. Percentiles were calculated accounting for all the countries with available data for that data source within the tropics (Table 1).

\subsection{Calculation of emissions}

The source of emissions was assessed by our framework based on the relative contribution of agricultural emissions and emissions from agriculture-driven deforestation to the sum of the two, which is hereafter referred to as total emissions (Table 1).

\subsubsection{Area of forest loss}

To estimate current deforestation driven by agriculture, we first estimated total deforestation areas based on a combination of historical data sets covering forest changes from 2000-2012 (Table 2). Since we focus on land-use changes (from forest to agriculture), deforestation data based on a forest land-use definition are required. Gross change data are required since, for example in China, India and Vietnam, 
Table 1. Data sources for the identification of target countries for mitigation interventions. Categories are selected by thresholds at the $1 / 3$ rd and $2 / 3$ rd percentiles.

\begin{tabular}{|c|c|c|c|c|}
\hline \multirow{2}{*}{\multicolumn{2}{|c|}{$\begin{array}{c}\text { Decision step } \\
\text { Emissions assessment }\end{array}$}} & \multicolumn{3}{|c|}{ Categories } \\
\hline & & Agriculture & Deforestation & Both \\
\hline \multirow[t]{2}{*}{$\begin{array}{l}\text { Total emissions } \\
\left(t \mathrm{CO}_{2} \mathrm{e}\right)\end{array}$} & $\begin{array}{l}\text { Emissions }\left(\mathrm{CO}_{2}\right) \text { which come from agriculture- } \\
\text { driven deforestation (multiple data sources - } \\
\text { see Sect. 2.2) and from agriculture }\left(\mathrm{CH}_{4}, \mathrm{~N}_{2} \mathrm{O} \text {, }\right. \\
\left.\mathrm{CO}_{2}\right) \text { (Emissions from agriculture } 2010 \text { [or most } \\
\text { recent data point available] } \\
\left.\left[t \mathrm{CO}_{2} \mathrm{e}\right]^{*} ; \mathrm{FAO}, 2014 \mathrm{~b}\right)\end{array}$ & $\begin{array}{l}>66 \% \text { is emissions } \\
\text { from agriculture- } \\
\text { driven deforesta- } \\
\text { tion }\end{array}$ & $\begin{array}{l}>66 \% \text { is agriculture } \\
\text { emissions }\end{array}$ & $\begin{array}{l}33-66 \% \text { is } \\
\text { emissions from } \\
\text { agriculture- } \\
\text { driven } \\
\text { deforestation } \\
\text { and agriculture }\end{array}$ \\
\hline & Mitigation potential & Low & Medium & High \\
\hline Yield gap $\left(\mathrm{tha}^{-1}\right)$ & $\begin{array}{l}\text { Area-weighted yield gap of major grains } \\
\text { (Neumann et al., 2010) based on the area } \\
\text { under production (Monfreda et al., 2008). }\end{array}$ & $<2.21$ & $2.21-3.6$ & $>3.6$ \\
\hline Available land (\%) & $\begin{array}{l}\text { Area of non-forested, non-protected, unused } \\
\text { land, with minor slopes }<15 \% \text { and a poten- } \\
\text { tial for }>3.5 \mathrm{tha}^{-1} \text { agricultural production. Ex- } \\
\text { pressed as a percentage of forested land (multi- } \\
\text { ple data sources - see Table } 2 \text { ). }\end{array}$ & $<17$ & $17-44$ & $>44$ \\
\hline \multirow[t]{2}{*}{$\begin{array}{l}\text { Agricultural emis- } \\
\text { sions }\left(t \mathrm{CO}_{2} \mathrm{e} \mathrm{ha}^{-1}\right)\end{array}$} & $\begin{array}{l}\text { Emissions }\left(\mathrm{CH}_{4}, \mathrm{~N}_{2} \mathrm{O}, \mathrm{CO}_{2}\right) \text { from agriculture } \\
2010 \text { (or most recent data point available; FAO, } \\
2014 \mathrm{~b} \text { ) }\end{array}$ & $<0.72$ & $0.72-1.68$ & $>1.68$ \\
\hline & Enabling environment & Low & Medium & High \\
\hline Governance & $\begin{array}{l}\text { Governance index (government effectiveness, } \\
\text { regulatory quality, rule of law and control } \\
\text { of corruption; World Bank, 2012) }\end{array}$ & $<-0.72$ & $-0.72-0.24$ & $>-0.24$ \\
\hline \multirow[t]{2}{*}{$\begin{array}{l}\text { REDD+ engage- } \\
\text { ment }\end{array}$} & $\begin{array}{l}\text { Index of engagement in national and } \\
\text { sub-national REDD+ initiatives } \\
\text { (multiple data sources - see Sect. 2.4) }\end{array}$ & $<0.14$ & $0.14-0.36$ & $>0.36$ \\
\hline & Risk assessment & Low & Medium & High \\
\hline Food security & $\begin{array}{l}\text { Global Food Security } \\
\text { Index (http://foodsecurityindex.eiu.com/) }\end{array}$ & $>51$ & $34-51$ & $<34$ \\
\hline
\end{tabular}

* $\mathrm{CO}_{2} \mathrm{e}$ - equivalent concentrations of other GHGs in terms of radiative forcing as carbon dioxide.

large-scale afforestation projects will lead to an underestimation of deforestation if net data are used (FAO, 2010). So far, no single data source exists which provides gross forest change with a forest land-use definition; the Forest Resources Assessment Remote Sensing Survey (FRA RSS) is sample data which does not cover the whole of the tropics. Therefore, we combined remote-sensing based forest-cover change data from Hansen or FRA RSS to derive a ratio of net forest change to forest loss "Net : Loss" (Fig. 3). We used this factor to estimate gross forest loss from the Food and Agriculture Organization of the United Nations Forest Resources Assessment (FAO FRA) data (Eq. 1).

Gross forest loss $=$ net forest change $\mathrm{FAO}_{\mathrm{FRA}}$

- Net : Loss Hansen or FRA RSS.

The Net:Loss factor was only calculated where both data sets (FAO FRA and Hansen or FAO FRA and FRA RSS) were in agreement about the direction of net change, i.e. both giving negative, or both positive or both no change. Since the number of samples within a country in the FRA RSS varied substantially (from 0 to 930) we used the standard error to determine if the FRA RSS should be used in the analysis. Where the mean was smaller than the standard error for either the loss or gain in that time period, we did not use the FRA RSS data. We prioritized the Net: Loss ratio for landuse (FRA RSS) over land-cover (Hansen) in Eq. (1).

Data from the FAO FRA are nationally reported and their accuracy is linked to the capacity of the country to provide the data (Romijn et al., 2012). We used this data only when the country was considered to be able to produce reliable data. Countries whose data we considered reliable were either high-income countries (World Bank, 2013), or countries which in 2010 had either an intermediate, high, or very high capacity to measure forest area change (Romijn et al., 2012). 
Table 2. Description of data sources used to derive deforestation at the national level.

\begin{tabular}{lrrrrrr}
\hline Data & Source & Gross/net & Forest-us /Forest-cover & Coverage & Resolution & Temporal coverage \\
\hline FAO FRA & FAO (2010) & Net & Forest-use & Complete & Country & $2000-2010$ \\
FRA RSS & FAO and JRC (2012) & Gross & Forest-use & Sample & Based on Landsat & $2000-2005$ \\
Hansen & Hansen et al. (2013) & Gross & Forest-cover & Complete & Based on Landsat & $2000-2012$ \\
\hline
\end{tabular}

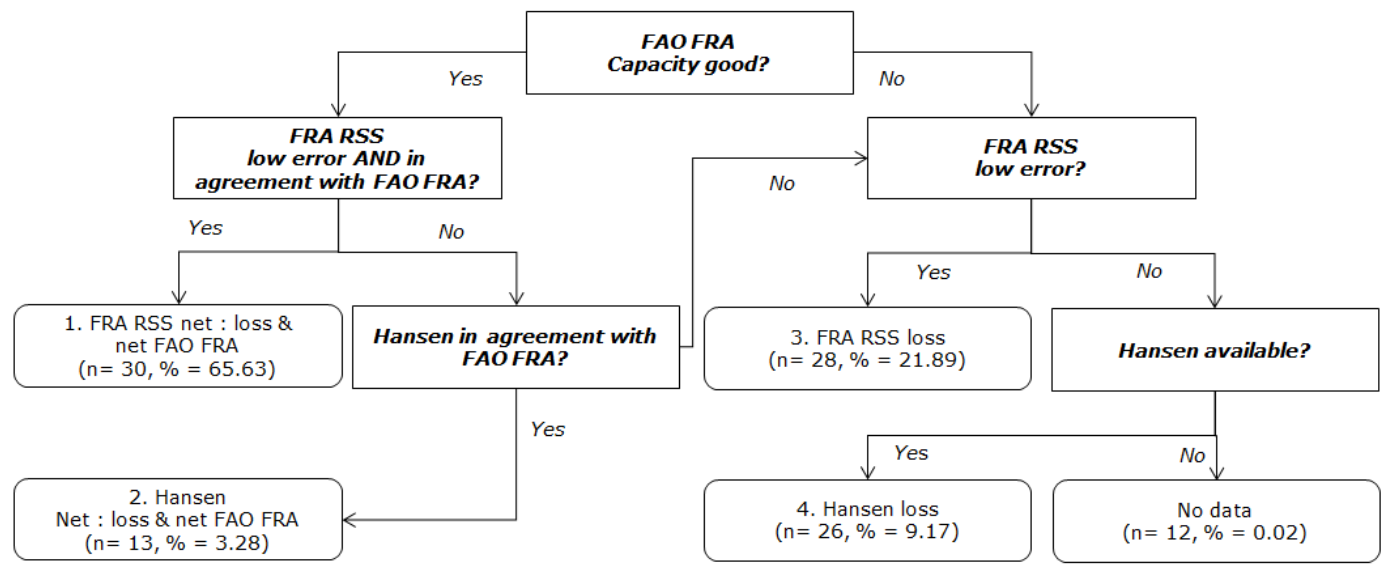

Figure 3. The decision tree for the selection of deforestation data. The decision numbers represent quality flags, 1 for the highest quality data and 4 for the lowest. $N=$ number of countries in that group, and $\%=$ percentage of forest in that group.

Romijn et al. (2012) evaluated the existing monitoring capacities of countries taking into consideration challenges such as the area of forest which the country has to monitor and availability of data.

Where the conditions described above were not met, and Eq. (1) is therefore unsuitable, we selected first the FRA RSS alone to provide the loss, and if this did not meet the error criteria based on the number of samples, we used the Hansen data alone, where it was available. Otherwise we recorded no data (no data was also recorded where only FAO FRA net change is available). Data are available for most of the tropics, and the 12 no-data countries (out of 109 countries) account for only $0.02 \%$ of forest area considered in this study. For the majority of the data (countries which hold more than $69 \%$ of forest in the tropics), loss was calculated using FAO FRA in combination with either FRA RSS or Hansen (Fig. 3).

For future projections of deforestation areas, a historical baseline period which is sufficiently long to compensate for any anomalous high and low years is required (Santilli et al., 2005). Here, we considered a period of 10 years, which is in line with other studies (e.g. Rideout et al., 2013).

\subsubsection{Area of forest loss due to agriculture}

Based on the national total area of deforestation we calculated the area that was deforested due to agriculture. In this study, we used the definition of deforestation drivers used by Hosonuma et al. (2012) and Kissinger et al. (2012). Drivers can be separated into direct and indirect drivers. Since the definition for deforestation considers a change in land use, timber extraction is not considered as a driver, as the forest is expected to regrow. Direct drivers relate to an intended land use (for example, urban expansion, mining, agriculture and infrastructure). Indirect drivers include international markets and population growth that influence the land change. We used national data from Hosonuma et al. (2012) describing the importance of agriculture as a direct driver of deforestation. Agriculture includes cropland, pasture, tree plantations and subsistence agriculture including shifting cultivation (Hosonuma et al., 2012). The authors derived the importance of deforestation drivers from a synthesis of nationally self-reported data, country profile reports from the Center for International Forestry Research (CIFOR) and other literature, most of them reflecting the time frame between 2000 and 2010. The relative importance of the drivers mentioned in the reports is quantified either as a ratio, ordinal, or nominal scale. These were scaled from 0 to 1 (representing minimal to high influence), to indicate the proportion of deforestation which is driven by agriculture (see Hosonuma et al., 2012 for details). We multiplied this agricultural driver factor by the area of forest loss deforestation to infer the area of loss driven by the agriculture: agriculture-driven deforesta- 
tion (Eq. 2).

Agriculture-driven deforestation $=$ deforestation

- agricultural driver factor.

According to the method used in Harris et al. (2012), we calculated emissions by multiplying the area of forest loss by an emissions factor. For the biomass emissions factor, we use the sum of above-ground biomass (AGB) and below-ground biomass (BGB). We averaged two AGB data sets derived from remote sensing and ground measurements; a tropical data set (Saatchi et al., 2011) and, a continental data set (Baccini et al., 2012). Using an average of the two maps is preferred (where there is coverage from both data sets), since the accuracy of both approaches is yet to be determined (Zolkos et al., 2013). Where only one map has data, we used the data set available. The mean AGB in each country was calculated in forested areas, which were selected using the ESA Global Land Cover map of 2010 developed in the Climate Change Initiative (CCI; ESA, 2013). BGB was calculated from AGB using tree root to shoot ratios equations (Mokany et al., 2006).

\subsubsection{Emissions from agriculture}

We used national emission data from FAO (2012) to calculate total emissions from agriculture, covering enteric fermentation, manure management, rice cultivation, synthetic fertilizers, manure applied to soils, manure left on pasture, crop residues, cultivation of organic soils, burning - savanna, burning - crop residues and agricultural soils. We do not account for sinks such as those which occur from crop regrowth. We excluded energy use in agriculture. According to FAO (FAO, 2014a) agriculture includes livestock, and agricultural land is defined as fallow land, temporary crops, temporary meadows for mowing and pasture, permanent crops and permanent meadows and pasture.

\subsection{Mitigation potential}

We consider two approaches to mitigate agriculture-driven deforestation; closing the yield gap and utilizing non-forest land for agricultural expansion. Additionally, where the majority of a country's total emissions are from agriculture, we estimate the potential to reduce these emissions through climate smart approaches in the agriculture sector. We define mitigation potential as the total mitigation which could be achieved over time. We do not consider practical constraints (technical potential), or cost limitations (economic potential; Baede et al., 2007).

\subsubsection{Closing the yield gap}

Production of maize, wheat and rice provides about twothirds of all energy in human diets (Cassman, 1999) and therefore, we focus on these three crop types in our analysis.
First, we calculated the average yield gap of these three cereals for each country based on Neumann et al. (2010). Second, we derived the crop-specific production area per country based on Monfreda et al. (2008). In our study, the yield gap at national level is calculated by the following function (Eq. 3), using yield gaps and production areas of each crop $(x)$.

cereal yield gap $=\sum \frac{\text { mean yield gap } x}{\text { total cereal area }}$

- cereal area $x$.

\subsubsection{Non-forested land suitable for agriculture}

We used a number of conditions to identify suitable agricultural land, where data are available across the tropics (Table 3, Fig. S1, in the Supplement). These conditions include (1) the biophysical potential; at minimum a moderate rainfed yield, low slope, and not barren and (2) the availability of land; not forested, not used for another purpose (agriculture, urban etc.), not used exclusively for agriculture (for example mosaic use with a non-use) and no protected areas. This is likely to result in an optimistic estimate of available land since socio-economic and regulatory barriers to land cultivation have not been considered.

\subsubsection{Potential for reduction of agricultural emissions}

Where the majority of emissions are in the agriculture sector (Fig. 1), we calculated the emissions $t \mathrm{CO}_{2} \mathrm{e}$ per hectare of agricultural land using national emissions data (Sect. 2.1.3), and agricultural area data (FAO, 2014b). High emissions show that there are emissions which could potentially be reduced.

\subsection{Enabling environment}

To represent the enabling environment for mitigating deforestation we used two indicators: governance and engagement in REDD+. To indicate governance, we summed the following components of a governance index, available from the World Bank (2012): government effectiveness, regulatory quality, rule of law and control of corruption.

We produced an index of REDD+ engagement taking into account (1) national engagement in international REDD+ initiatives, (2) sub-national engagement in REDD+ initiatives through project development, and (3) amount of funding acquired. We gave equal weight to the following international programmes: UN-REDD (United Nations Collaborative initiative on Reducing Emissions from Deforestation and forest Degradation (REDD) in developing countries), FCPF (Forest Carbon Partnership Facility), CIF-FIP (Forest Investment Plan (FIP) within the Climate Investment Funds; CIF), GEF (The Global Environment Facility), and the Governors' Climate and Forests Task Force. Due to varying levels of participation in some initiatives, weightings were given. We weighted countries receiving support from the UN-REDD 
Table 3. Land available for agriculture - data sources and availability conditions.

\begin{tabular}{lll}
\hline Availability factor & Availability condition & Data description \\
\hline $\begin{array}{l}\text { Yield potential for } \\
\text { rainfed agriculture }\end{array}$ & crop productivity $>3.5 \mathrm{tha}^{-1}$ & $\begin{array}{l}10 \text { arc minute climate data set combined with } \\
\text { soil water storage map and a dynamic water } \\
\text { and crop model (Droogers et al., 2001) }\end{array}$ \\
\hline $\begin{array}{l}\text { Land is not used and } \\
\text { non-forested }\end{array}$ & $\begin{array}{l}\text { Mosaic cropland/tree cover, mosaic } \\
\text { herbaceous/tree cover, } \\
\text { shrubland and grassland cover classes }\end{array}$ & $\begin{array}{l}300 \mathrm{~m} \text { resolution land cover map based on a } \\
\text { global surface reflectance (SR) composite } \\
\text { time series. Data for 2010 available (ESA, } \\
\text { 2013) }\end{array}$ \\
\hline $\begin{array}{l}\text { Suitable topography } \\
\text { for agriculture }\end{array}$ & Slopes < 15\% & $\begin{array}{l}\text { 30 arc second aggregate based on 90 m reso- } \\
\text { lution digital terrain map from the Shuttle } \\
\text { Radar Topographic Mission (SRTM; Fischer } \\
\text { et al., 2008) }\end{array}$ \\
\hline $\begin{array}{l}\text { Land does not have } \\
\text { protected area status }\end{array}$ & No protected status & $\begin{array}{l}\text { Globally spatially referenced database of } \\
\text { protected areas (IUCN UNEP-WCMC, 2014) }\end{array}$ \\
\hline
\end{tabular}

by one, and partner countries by one-half. There are several steps in the process to gaining an emissions reduction purchase agreement (ERPA) within the FCPF Carbon Fund, so we weighted countries who participate (signing a partnership agreement, but yet to submit any documents) by onethird, countries who submitted the RPIN (Readiness Plan Idea Note) by two-thirds, and countries with a finalized RPP (Readiness Preparation Proposal) by one. Funding acquisition data were acquired from the Climate Funds Update (www.climatefundsupdate.org), we allocated scores between 0 and 1 depending on the amount secured. The number of REDD+ projects which are occurring in a country are available from the CIFOR database (www.forestclimatechange. org/redd-map/), and we gave scores between 0 and 1 depending on the number of projects (Table S1 in the Supplement). We summed all the scores per country and divided by 7 (the maximum summed score) to create the index for REDD+ engagement with a final score of between 0 and 1 .

\subsection{Risk assessment}

We assessed the risk to livelihoods potentially resulting from the implementation of the mitigation interventions. Risk is dependent on many elements, which can be grouped into three components: hazard (physical realization of the risk), exposure (elements exposed to the risk) and vulnerability (susceptibilities of the exposed elements); (Cardona et al., 2012). We consider that the hazard (a system change leading to changes to land use) occurs, and that the exposed elements are local communities. We then use a food security index as a proxy for vulnerability, reflecting risk as a whole (http://foodsecurityindex.eiu.com/).

\section{Results}

\subsection{Sources of emissions}

In the tropics, a total of $104260 \mathrm{~km}^{2} \mathrm{yr}^{-1}$ of forest on average was lost between 2000 and 2010/12 (dependent on data input; see Fig. 3) to agriculture (97 countries), which resulted in $4.26 \mathrm{GtCO}_{2} \mathrm{yr}^{-1}$ emitted to the atmosphere (Fig. 4). The largest forest loss due to agriculture occurred in Brazil $\left(29470 \mathrm{~km}^{2} \mathrm{yr}^{-1}\right)$. On average, countries lost $0.52 \% \mathrm{yr}^{-1}$ of their forest to agriculture, with the highest percent loss in Togo $\left(3.71 \% \mathrm{yr}^{-1}\right)$.

The emissions are categorized as follows (Table 1): (1) agriculture-driven deforestation emissions are the main source of the total emissions (> 66\%); (2) agricultural emissions are the main source of the total emissions (> $66 \%$ ) and (3) agriculture-driven deforestation and agriculture each contribute $33-66 \%$ to the total emissions. Those countries where emissions from deforestation are highest include those which have high forest losses due to agricultural expansion, e.g., Zimbabwe $1.35 \% \mathrm{yr}^{-1}\left(2548 \mathrm{~km}^{2} \mathrm{yr}^{-1}\right)$, and those with a large forest area, e.g., Brazil which loses $0.54 \% \mathrm{yr}^{-1}$ (Figs. 4 and 5). Some countries with high agricultural emissions have no deforestation due to agriculture (United Arab Emirates, Djibouti, Eritrea, Mauritania, Niger, Oman, Saudi Arabia). Haiti is an exception which has a high forest loss due to agriculture $\left(>2 \% \mathrm{yr}^{-1}\right)$ but most emissions are from the agricultural sector due to the small forest area remaining $\left(1090 \mathrm{~km}^{2}\right.$ in $2000, \sim 4 \%$ of the country area).

\subsection{Mitigation potential of agriculture-driven deforestation}

In total, 78 countries were classified according to their mitigation potential using the decision tree (Fig. 2); the main results are presented in Table 4 . Out of 44 countries with 


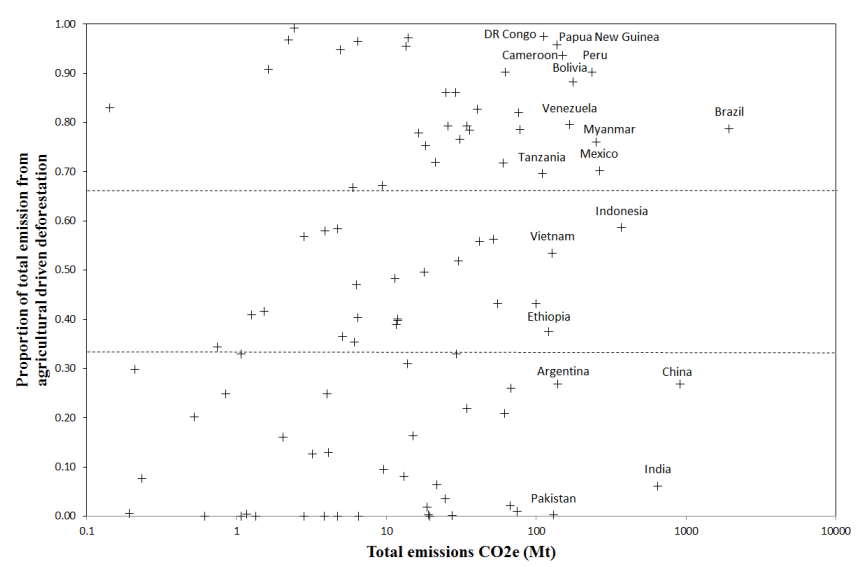

Figure 4. Total $\mathrm{CO}_{2}$ emissions (annual $\mathrm{AGB}$ and $\mathrm{BGB}$ removals on forest land converted to agriculture (2000-2010/12) plus annual agricultural emissions, 2010), and the proportion of the total emissions from agricultural-driven deforestation $(1=100 \%$ emissions from agricultural-driven deforestation, $0=100 \%$ emissions from agriculture). The 17 countries with emissions $>100 \mathrm{Mt}$ are labelled $(n=95)$. The horizontal lines distinguish the groups where total emissions are $>66 \%$ from agriculture (lower third), 33-66\% from agriculture-driven deforestation and agriculture (middle third) and $>66 \%$ (middle third) from agriculture-driven deforestation.

$>33 \%$ of the total emissions from agriculture-driven deforestation, 33 countries also have either a high yield gap or a large area of available land compared to forest land (Table 4). Available land is highest in South East Asia and West Africa (Fig. 6). The yield gap is highest in East and Central Africa and Central America with the yield gap being already closed in much of Asia and South America (Fig. 6). Of those countries with a high yield gap or large area of available land 20 countries have a good enabling environment in terms of effective governance or engagement in REDD+. These countries have a mitigation potential of $1.32 \mathrm{GtCO}_{2} \mathrm{yr}^{-1}$ from reducing agriculture-driven deforestation. Most countries in Asia and South and Central America have strong enabling environments for interventions, with either effective governance or involvement in REDD+ (Fig. 6). Central Africa has high engagement in REDD+ and some countries in Southern Africa have a high governance scores. Sub-Saharan Africa has the weakest enabling environment for mitigation interventions. Food insecurity indicates a risk to livelihoods when implementing mitigation interventions, and 14 out of the remaining 20 countries have high risks (Table 3 ). Six priority countries have been identified, which have potential to mitigate agriculture-driven deforestation, and also have a good enabling environment and low risks associated with implementing an intervention: Panama, Paraguay, Ecuador, Mexico, Malaysia and Peru (Table 4).

\subsection{Mitigation potential of agricultural emissions}

Thirty-eight countries with either $>66 \%$ of total emissions from agriculture or 33-66\% of total emissions from agriculture and no mitigation potential through land-sparing (Fig. 2) were assessed for the potential to mitigate emissions from agriculture. Of those 38 countries, 12 have a potential to mitigate up to $1 \mathrm{GtCO}_{2} \mathrm{e} \mathrm{yr}^{-1}$ of agricultural emissions. However, only two countries have a good enabling environment, and of those only Thailand has low risks associated with the implementation of interventions, so mitigation potential is low. Implementing intervention in countries with associated risks would require an emphasis on safeguarding.

\subsection{Priority areas for increased support}

A number of countries have either little engagement in REDD+ or poor governance which represents a barrier to a successful implementation of interventions. There are 13 countries with more than $33 \%$ of their emissions originating from agriculture-driven deforestation, which have a high potential for mitigation through land-sparing but lack a supportive enabling environment. This accounts for $8 \%$ of emissions from agriculture-driven deforestation. These countries should be assessed for the potential to implement interventions along with capacity-building initiatives. Priority candidates for increased support in REDD+ activities are those which have $>66 \%$ of total emissions from agriculture-driven deforestation and which have a high potential for mitigation of agriculture-driven deforestation (Honduras, Liberia, Nicaragua, Venezuela, Zambia and Zimbabwe). Where the mitigation potential in the agriculture sector is highest, there are a number of countries which would require increased support (Bangladesh, Egypt, Gambia, Haiti, Nepal, Pakistan, Philippines and El Salvador).

\section{Discussion}

\subsection{The potential for mitigation of emissions from agriculture-driven deforestation and agriculture}

Our results quantify annual forest losses which are driven by agriculture. Converting forest loss to emissions, and comparing this to emissions from agriculture allows mitigation approaches for the main source to be considered. We consider emissions to indicate the need for mitigation rather than forest area loss, which gives a focus on countries with high carbon forests. This can lead to valuable wooded ecosystems being neglected (Mbow, 2014). However, countries with low carbon forests do appear in our study and are highlighted as priorities for action (e.g. Zambia, Togo).

Following this, we consider the enabling environment and risks to identify priority countries. This assessment can be used as a starting point for national priority setting and policy processes. However countries with a low potential for 
Table 4. Countries are categorized into mitigation intervention classes according to the results of the decision-making tree (Fig. 1) which identifies target countries for mitigation interventions using thresholds for input data (Table 1). Priority countries (with low risks) for interventions are emboldened (countries for which data are unavailable for the full analysis are not included).

\begin{tabular}{|c|c|c|c|c|}
\hline $\begin{array}{l}\text { Contribution of emis- } \\
\text { sions to total }\end{array}$ & Agriculture $>66 \%$ & \multicolumn{2}{|c|}{$\begin{array}{l}\text { Agriculture and agricultural-driven } \\
\text { deforestation emissions 33-66\% }\end{array}$} & $\begin{array}{l}\text { Agricultural-driven deforestation } \\
>66 \%\end{array}$ \\
\hline $\begin{array}{l}\text { Potential for } \\
\text { mitigation (sector) }\end{array}$ & Agriculture & Agriculture & Forest & Forest \\
\hline $\begin{array}{l}\text { High potential and effec- } \\
\text { tive governance } \\
\text { (or engagement in } \\
\text { REDD+ in the case of } \\
\text { the agriculture mitiga- } \\
\text { tion sector) for } \\
\text { mitigation intervention } \\
\text { (low risk countries are } \\
\text { emboldened) }\end{array}$ & $\begin{array}{l}\text { Thailand } \\
\text { India }\end{array}$ & & $\begin{array}{l}\text { Panama } \\
\text { Paraguay } \\
\text { Indonesia } \\
\text { Kenya } \\
\text { Sri Lanka } \\
\text { Madagascar } \\
\text { Senegal } \\
\text { Uganda } \\
\text { Vietnam }\end{array}$ & $\begin{array}{l}\text { Ecuador } \\
\text { Mexico } \\
\text { Malaysia } \\
\text { Peru } \\
\text { Côte d'Ivoire } \\
\text { Cameroon } \\
\text { DR Congo } \\
\text { Ghana } \\
\text { Guatemala } \\
\text { Mozambique } \\
\text { Tanzania }\end{array}$ \\
\hline $\begin{array}{l}\text { High potential but sup- } \\
\text { port for governance re- } \\
\text { quired } \\
\text { (countries are not as- } \\
\text { sessed for risk) }\end{array}$ & $\begin{array}{l}\text { Bangladesh } \\
\text { Egypt } \\
\text { Gambia } \\
\text { Haiti } \\
\text { Nepal } \\
\text { Pakistan } \\
\text { Philippines } \\
\text { El Salvador }\end{array}$ & $\begin{array}{l}\text { Dominican Repub- } \\
\text { lic } \\
\text { Suriname }\end{array}$ & $\begin{array}{l}\text { Angola } \\
\text { Benin } \\
\text { Ethiopia } \\
\text { Guinea } \\
\text { Malawi } \\
\text { Sierra Leone } \\
\text { Togo }\end{array}$ & $\begin{array}{l}\text { Honduras } \\
\text { Liberia } \\
\text { Nicaragua } \\
\text { Venezuela } \\
\text { Zambia } \\
\text { Zimbabwe }\end{array}$ \\
\hline $\begin{array}{l}\text { Low potential (coun- } \\
\text { tries are not assessed } \\
\text { for governance or risk) }\end{array}$ & $\begin{array}{l}\text { Argentina } \\
\text { Burundi } \\
\text { Burkina Faso } \\
\text { Chile } \\
\text { China } \\
\text { Comoros } \\
\text { Cuba } \\
\text { Djibouti } \\
\text { Algeria } \\
\text { Eritrea } \\
\text { Jamaica } \\
\text { Libya } \\
\text { Mali } \\
\text { Mauritania } \\
\text { Mauritius } \\
\text { Niger } \\
\text { Nigeria } \\
\text { Oman } \\
\text { Rwanda } \\
\text { Saudi Arabia } \\
\text { Somalia } \\
\text { Chad } \\
\text { Uruguay } \\
\text { South Africa }\end{array}$ & $\begin{array}{r}\mathrm{C} \\
\text { Guir }\end{array}$ & $\begin{array}{l}\text { ombia } \\
\text { a-Bissau }\end{array}$ & $\begin{array}{l}\text { Bolivia, } \\
\text { Brazil } \\
\text { Costa Rica } \\
\text { Guyana } \\
\text { Cambodia } \\
\text { Lao PDR } \\
\text { Myanmar }\end{array}$ \\
\hline
\end{tabular}

mitigation should also be assessed at the sub-national level for opportunities. In addition, risks should be assessed at the local level and even where low risks are identified, activities should be accompanied by safeguards that ensure that the rights and livelihoods of local communities and biodiversity are respected (Peskett and Todd, 2013). REDD+ interventions can potentially bring benefits to communities, but can also bring negative impacts resulting from restric- 
a)

Agriculturally driven forest

loss $(\% / \mathrm{y})$

$<=0.5$
$0.5-1$
$1-1.5$
$>1.5$

b)

Proportion of emissions from agriculture and agriculturally driven deforestation

Agriculture
Both
Deforestation
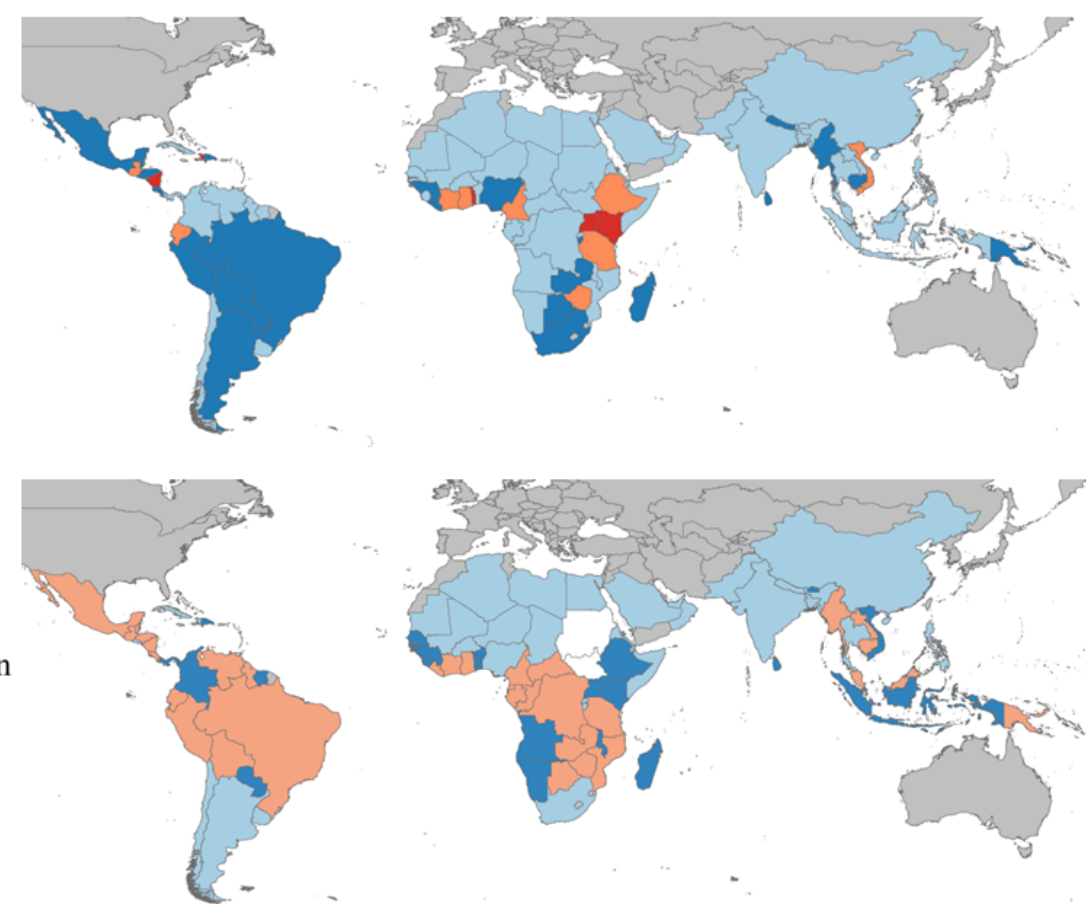

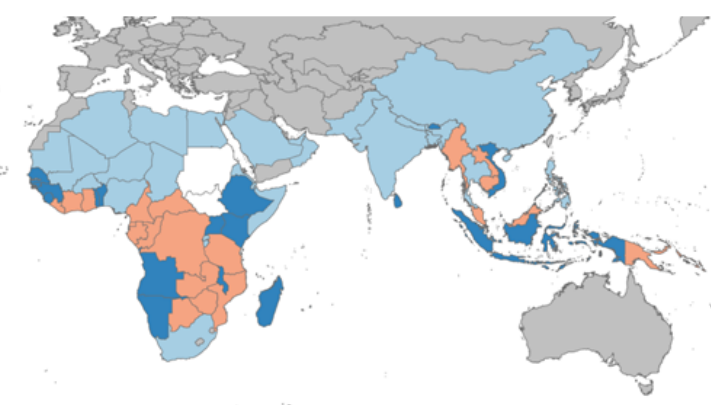

Figure 5. Emissions sources (a) \% agriculturally driven forest area loss (b) proportion of emissions from agriculture and agriculture-driven deforestation (expressed as a proportion of the total emissions "agriculture" $=>66 \%$ from agriculture, "both" $=33-66 \%$ from agriculturedriven deforestation and agriculture and "deforestation" $=>66 \%$ from agriculture-driven deforestation). Grey areas are outside the study area, and white areas had no available data.
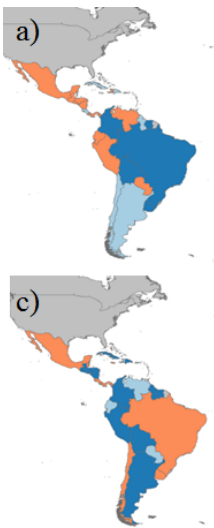
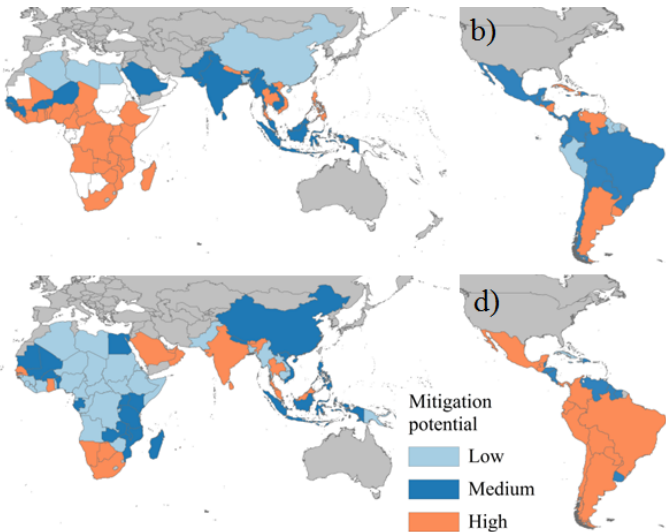
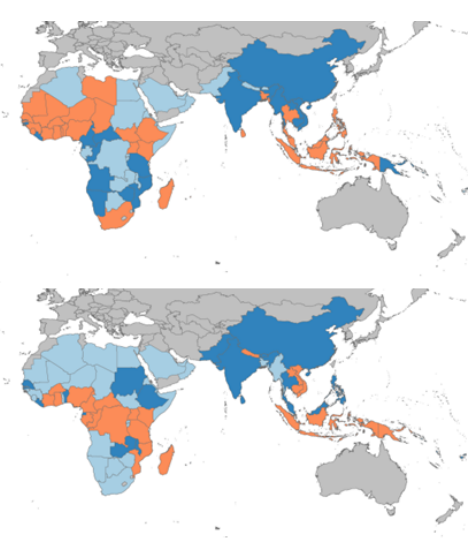

Figure 6. Mitigation potential through (a) closing the yield gap, and (b) utilizing available land, and enabling environment through (c) Governance and (d) REDD+ engagement. Grey areas are outside the study area, and white areas had no available data.

tions on access to forests, changes to permitted land management practices (Peskett and Todd, 2013), or altered agricultural practices (Smith et al., 2013). The likelihood that negative impacts will result is dependent on, among other things, the safeguarding systems implemented with the intervention (Peskett and Todd, 2013).

We explored three national case studies in more detail, providing recommendations for the mitigation of emissions from both agriculture-driven deforestation and from agricul- ture (Table 5). Two cases represent the potential to mitigate deforestation-related emissions (Democratic Republic of Congo (DR Congo) and Indonesia), and one case study highlights the case for targeted interventions within the agricultural sector (Argentina). All countries have emissions $>1 \mathrm{GtCO}_{2} \mathrm{e} \mathrm{yr}^{-1}$ (Fig. 2), and have supporting data available to evaluate the use of the framework for the assessment of the mitigation potential. 
Table 5. Mitigation potential for DR Congo, Indonesia and Argentina.

\begin{tabular}{lrrr}
\hline & DR Congo & Indonesia & Argentina \\
\hline Emissions source & Deforestation & Both & Agriculture \\
\hline Mitigation potential & $\begin{array}{r}\text { Reducing } \\
\text { deforestation }\end{array}$ & $\begin{array}{r}\text { Reducing } \\
\text { deforestation }\end{array}$ & $\begin{array}{r}\text { Agricultural } \\
\text { sector }\end{array}$ \\
\hline Yield gap & High & Medium & Low \\
Available land & Low & High & High \\
Agricultural emissions & Low & High & Low \\
\hline Enabling environment & Yes & Yes & No \\
Governance & Low & Medium & Medium \\
REDD+ engagement & High & High & High \\
\hline Risk factor & Yes & Yes & No \\
\hline Food insecurity & High & Medium & Low \\
\hline
\end{tabular}

\subsubsection{Case study: DR Congo}

Emissions from agriculture-driven deforestation in the DR Congo account for $98 \%$ of the total emissions (emissions from agriculture plus agriculture-driven deforestation). There is a strong consensus that the major direct driver of deforestation in DR Congo is agriculture, and due to increasing populations and weak governance, deforestation rates are likely to increase in the future (Ickowitz et al., 2015). A high mitigation potential exists to reduce agriculture-driven deforestation given the high yield gap, although available land is rated low $(\sim 12 \%)$. Reports suggest that one of the major barriers to the implementation of interventions in agriculture is the lack of transport infrastructure and access to markets (Ickowitz et al., 2015). However, engagement in REDD+ is high, suggesting a strong enabling environment for landuse related interventions. Vulnerable communities may be affected by land-based activities, since DR Congo is food insecure. Roots, tubers and plantains comprise more than half of the dietary requirements in the DR Congo and a fall in production over recent years has led to a fall in the average caloric intake (Alexandratos and Bruinsma, 2012). Together with the country's state of post-conflict recovery this suggests that food insecurity will remain in the near future.

\subsubsection{Case study: Indonesia}

In Indonesia $41 \%$ of the total agriculture and agriculturedriven deforestation emissions originate from agriculture. Since Indonesia has available land approximately half the area of its forests, and a relatively small yield gap $\left(2.22 \mathrm{th}^{-1}\right)$, the identification of unused land could be explored as a priority. Caution should be taken since the conversion of Indonesia's high carbon peat swamps can lead to a large flux of emissions - in the case of palm oil this is a change from a net of -1.3 to $30.4 \mathrm{MgCO}_{2} \mathrm{eha}^{-1} \mathrm{yr}^{-1}$ (Hergoualc'h and Verchot, 2013). Amongst all countries in- cluded in our analysis Indonesia has the highest engagement in REDD+, and has already implemented national policy interventions designed to protect forests from conversion to agriculture, such as a moratorium on forest conversion (Angelsen et al., 2012). However Indonesia is a major producer of oil palm and this has led to an expansion of agricultural land (Alexandratos and Bruinsma, 2012) so coordination from the agriculture and forestry sectors is required where there is competition for land. In terms of risks, Indonesia faces some food insecurity, so this should be considered and monitored to ensure that unwanted trade-offs do not result from interventions.

\subsubsection{Case study: Argentina}

In Argentina, $73 \%$ of the total emissions from agriculturedriven deforestation and agriculture, originate from agriculture. Argentina has the 8th highest (average 1990-2011) agricultural emissions in the world - largely resulting from livestock keeping (FAO, 2014b), and it is expected that these emissions will continue to rise due to increasing beef demand, so advances in the livestock sector need to be explored for assessing the potential for emissions reductions. In terms of addressing the proportion of emissions in Argentina occurring from agriculture-driven deforestation, there is a large area of available land (our study predicts that this is around $122 \%$ of the forest area) so there is a potential to avoid deforestation. Successful interventions such as a tax on soybean exports (Kissinger et al., 2012), which are driving land acquisitions (www.landmatrix.org) have also contributed to reduced expansion of agriculture land. Although our study finds a relatively low yield gap $\left(1.78 \mathrm{tha}^{-1}\right)$ there is still room to narrow, so land sparing could potentially occur from an intervention targeting the yield gap. Governance is medium in Argentina ( -0.35 ) so interventions are likely to be successful, although some capacity building could be integrated into interventions in the short term, since Argentina's 
R-PP states that insufficient law enforcement is one of the indirect drivers of deforestation (Kissinger et al., 2012).

\subsection{Calculating emissions from deforestation}

A number of studies have calculated emissions from recent deforestation. Achard et al. (2014) use the FRA RSS sample data (see Sect. 2.1.1) and find emissions between 2.2 and $4.3 \mathrm{GtCO}_{2} \mathrm{yr}^{-1}$ between 2000 and 2010. We find emissions of $5.14 \mathrm{GtCO}_{2} \mathrm{yr}^{-1}$ for the tropics, which are $13 \%$ higher than Achard et al. (2014). For 73 tropical countries (excluding the Caribbean), Harris et al. (2012) finds emissions of $1.9-4.73 \mathrm{Gt} \mathrm{CO}_{2} \mathrm{yr}^{-1}$ between 2000 and 2005 from deforestation. Our estimate for the same 73 countries is $4.83 \mathrm{GtCO}_{2} \mathrm{yr}^{-1}, 2 \%$ above the upper limit for Harris et al. (2012). Although our results are higher than these estimates, Harris' estimates are typically lower than other recent estimates (Harris et al., 2012), which supports our findings. In terms of the area of deforestation, Harris et al. (2012) find annual forest loss for 73 tropical countries (excluding the Caribbean) of $36750-143330 \mathrm{~km}^{2} \mathrm{yr}^{-1}$ (with a median of 85160 ). This supports our results for the same countries (we estimate $117486 \mathrm{~km}^{2} \mathrm{yr}^{-1}$ total forest loss not only driven by agriculture), which lies within the same range. Estimates of deforestation area from Achard et al. (2014) are not easily comparable to estimates based on country reported data (including our study) and disagree with the FAO FRA data partly due to the definition of forests (Achard et al., 2014). The major difference between estimates stems from the emissions factors rather than the activity data. Since our study uses a comparative approach to assess the need for mitigation on a country level, we consider these data to be still useful for this purpose. Emissions from deforestation can also be higher than we predict, as these studies do not consider losses from peat soils, burning of the forest or other GHGs.

\subsection{Projecting agriculture-driven deforestation}

Estimates of the mitigation potential of reducing agriculturedriven deforestation are inherently reliant on future estimates of agriculture-driven deforestation. These projections rely on assumptions about the future and baseline setting which is one of the challenges of REDD+ (Köthke et al., 2014). Historical deforestation rates are commonly used for setting business-as-usual (BAU) baselines for avoided deforestation (Santilli et al., 2005). We therefore selected this approach for our study, however other approaches may lead to more reasonable estimates. For example, adjusting historic baselines based on the forest transition curve (FT) to make projections can be beneficial since countries at the early stages of the transition will otherwise underestimate future BAU deforestation and countries at later stages of the transition will overestimate BAU (Angelsen, 2008; Köthke et al., 2014). However, future scenarios should also account for global economic forces and government policies which are not ac- counted for in the FT, and there are a number of countries which do not fit into the typical FT trajectory, for example Thailand (Meyfroidt and Lambin, 2011). Simulation models are often used to estimate deforestation based on relationships between deforestation and variables such as population, and have been used for a number of applications (Kaimowitz and Angelsen, 1998). Global models are useful for estimating deforestation since they account for leakage across national borders, and partial equilibrium models (e.g. GLOBIOM) are able to model competition for land by accounting for multiple sectors, e.g. agriculture, forestry and bioenergy. However, there is not always a clear relationship between deforestation and the selected explanatory variables, and some aspects of human behaviour such as social and political changes are impossible to predict, consequently leading to projections with high uncertainties (Dalla-Nora et al., 2014; Kaimowitz and Angelsen, 1998). In addition, there is some scepticism on models which are based on assumptions about economic behaviour, and those models which are based on household data are considered most reliable, which are only useful for local level estimates (Kaimowitz and Angelsen, 1998).

\subsection{Estimating available land}

Land available for agriculture is one of the indicators for the potential to mitigate agricultural expansion into forests. However, there are many difficulties in quantifying available land (Lambin et al., 2013). There are several limitations to our approach including: (1) the rain-fed potential productivity is considered, which can be exceeded by irrigation, (2) the applied threshold for the minimum potential productivity of $3.5 \mathrm{tha}^{-1}$ can be considered overly conservative, since many areas are cultivated with lower production levels (Droogers et al., 2001), (3) suitability for agriculture is crop specific, so it is possible that there are some crop types which can potentially produce above $3.5 \mathrm{tha}^{-1}$ in the very-low productivity areas, (4) it is a static approach which does not take into account likely impacts of future climate change on crop production (Frieler et al., 2015; Rosenzweig et al., 2014), (5) the land cover classes used in the availability criteria imply availability, but can also include some land already in use (6) we excluded slopes above $15 \%$, which can, however, potentially be cultivated using terracing. The $15 \%$ slope threshold, however, is commonly used to identify agricultural suitability at large scale since this is the threshold where the kinetic energy of the runoff increases and outweighs the kinetic energy of the rainfall thus resulting in erosion (Roos, 1996). Regarding the implied land availability, we acknowledge that some areas may not be available, for example grazed areas may not be in the agriculture land cover class of the land cover data set. Promoting agriculture expansion in areas which are used by local communities can lead to negative effects (Mbow, 2010). Yet, land availability was used to indicate the amount of available land rather than identifying areas for agricultural development, which requires local evaluation including risk 
Table 6. Available land area (in ' $000 \mathrm{~km}^{2}$ ) for three regions.

\begin{tabular}{llrrc}
\hline Source & Availability definition & $\begin{array}{c}\text { DR } \\
\text { Congo }\end{array}$ & $\begin{array}{c}\text { Indonesia } \\
\text { This study }\end{array}$ & $\begin{array}{c}\text { Brazilian and } \\
\text { Bolivian Amazon* }\end{array}$ \\
\hline \multirow{2}{*}{ (Lambin et al., 2013) } & $\begin{array}{l}\text { All available land } \\
\text { Land cover classes with potential } \\
\text { for agricultural expansion (1) }\end{array}$ & 854 & 638 & 385 \\
\cline { 2 - 5 } & $\begin{array}{l}\text { Areas excluding those } \\
\text { with major constraints (2) }\end{array}$ & 240 & 75 & 124 \\
\cline { 2 - 5 } & $\begin{array}{l}\text { Areas excluding those } \\
\text { with trade-offs (3) }\end{array}$ & 140 & 50 & 74 \\
\hline
\end{tabular}

* The Brazilian and Bolivian Amazon region consists of Bolivia, and five states in Brazil; Maranhão, Pará, Mato Grosso, Rondônia, and Acre (the Lambin et al. (2013) area is slightly smaller, as it only considers Pará south of the Amazon River, which is the "Amazon arc of deforestation").

assessments. Despite its limitations, comparisons with other data sets support our approach. Within the tropics we find approximately $8290000 \mathrm{~km}^{2}$ of available land (Fig. S1). This is over $11 \%$ of the total terrestrial area. Other studies also suggest that there are large areas of land available globally, for example Campbell et al. (2008) finds that over $3.5 \%$ of the land area is suitable for bioenergy production when only considering abandoned agricultural land. Lambin et al. (2013) calculated available land, and we compared three areas for which data are available with our own study, and they are within the same range (Table 6). Lambin et al. (2013) used a bottom-up approach to estimate the world's potentially available cropland based on a series of constraints and trade-offs which are considered in different scenarios. A global figure of $13220000 \mathrm{~km}^{2}$ was calculated using comparable processes, which is also within the same order of magnitude as our findings (Fader et al., 2013).

\subsection{The land-sparing hypothesis}

To spare land the yield gap needs to be sufficiently decreased or even closed, and available land needs to be successfully used. The extent to which the yield gap can be closed in practice depends on location-specific technological, biophysical and other constraints (Duwayri et al., 2000; Neumann et al., 2010). It is widely recognised that technological advances in agriculture, which improve production can reduce the need to expand agricultural production into forests (Borlaug, 2007; Stevenson et al., 2013). Yield gaps vary within countries (Table S2), and areas where yield gaps are highest may be targeted for interventions. Scenarios suggest that a $1 \%$ crop yield increase annually would spare 0.76 billion ha of cropland expansion by 2050 (Sands and Leimbach, 2003). Despite increases in fertilizer use, higher yields can reduce emissions, due to a reduced emissions intensity from production (Burney et al., 2010). In order to avoid social and environmental costs of agricultural intensification, including increased emissions, climate smart or sustainable intensifica- tion principles can be followed (Foley et al., 2011; Garnett, 2012). This theory, however, has been much debated recently, with some research finding that any savings will be offset by changing human diets and increased population (Bajzelj et al., 2014; Kastner et al., 2012).

Few examples are cited in the literature where intensification or utilization of available land has led to land-sparing (Cohn et al., 2011; Minang et al., 2011; Stevenson et al., 2013), perhaps since few programmes are developed with this aim. However, in the case of Brazil, Nationally Appropriate Mitigation Actions (NAMAs) to restore grazing land account for $10-12 \%\left(0.1-0.13 \mathrm{Gt} \mathrm{CO}_{2}\right)$ of pledged emission reductions for the year 2020 (Cohn et al., 2011). Despite the potential for emissions reductions from utilizing available land, there will always be emissions created from the utilization of these lands (Searchinger et al., 2015). However, when weighted against potential deforestation emissions, the carbon balance can be tipped in favour of conversion of available lands. In addition, where available lands are degraded (one of the reasons land is not currently utilized), rehabilitating them can increase the carbon storage capacity of soils, so adding to the mitigation potential (Smith et al., 2008).

Even if the yield gap has been closed, and available land utilized, land-sparing must become a reality in order for deforestation to be reduced. Some studies suggest that feedbacks such as increasing land rents from yield improvements will lead to increases in land area dedicated to agriculture (Angelsen, 2010). Intensified production has been found more likely than smallholder production to expand into forests (Gutiérrez-Vélez et al., 2011) and freeing grazing lands can lead to more demand for cropland to supply feed for the livestock (Cattaneo, 2001). However, we consider the level of governance as a criterion in the selection of areas for interventions which will support the integration of policies to limit agricultural expansion such as LSPs (Cohn et al., 2011; Rudel et al., 2009). Governance indicators, such as rule of law and control of corruption (World Bank, 2012) are related to the effective set-up and management of interventions and 
accompanying policies, and have been used as an indicator of the enabling environment for interventions. The state of Mato Grosso in Brazil is one example where agriculture-driven deforestation has been reduced by the integration of policies including the soybean industry's self-imposed moratorium (2006) on production in deforested areas and pro-active efforts by the local and national governments to control deforestation (DeFries et al., 2013). Although national level governance may be good, central governments may not support community level actions, so a multilevel system is important (Angelsen, 2010). NAMAs can also help to achieve targets of agricultural mitigation, can help to reduce leakage risks and foster wider engagement at the country level, and can be combined within REDD+ mechanisms (Kissinger et al., 2012).

\section{Conclusions}

This study gives a comprehensive overview of national emissions and mitigation priorities within the forest and agriculture sectors, which can guide decision making and investments at the international level. Specifically, we have demonstrated how available data can be used to identify where emissions from agriculture, forestry and other land use (AFOLU) sector within the IPCC reporting scheme can be best reduced. The inherent link between agriculture and forests highlights the need for integrated solutions. Agricultural interventions have been incorporated into REDD+ frameworks in some countries, including Indonesia and Brazil (Kissinger et al., 2012). Yet, there is potential for improvement to ensure that where agricultural drivers are present, those are addressed with appropriate interventions within the agricultural sector (Salvini et al., 2014). This task is not without difficulties, since government agencies focusing on agriculture and those focusing on forestry may have differing objectives, and a systematic incorporation of policies is required to consider competing goals. In addition, if interventions are implemented in the agricultural sector to spare forest land, then support from the forestry sector is also necessary to protect existing forests.

Our findings show a mitigation potential of $4.26 \mathrm{GtCO}_{2} \mathrm{e} \mathrm{yr}^{-1}$ from agriculture-driven deforestation. Many countries also have a high potential to implement successful interventions in the agricultural sector, as there is a good enabling environment (effective governance or engagement in REDD+) which will support activities. A potential of $1.32 \mathrm{GtCO}_{2} \mathrm{yr}^{-1}$ can be mitigated in those countries in which more than one third of their emissions stem from agriculture-driven deforestation and which have a good enabling environment (20 countries). These countries are responsible for $31 \%$ of the total emissions from agriculture-driven deforestation in the tropics. They potentially hold the easiest gains and interventions which seek to spare forest land by decreasing the yield gap, or by expanding agriculture into available non-forest lands and these opportunities should be systematically considered. Some of these countries have risks (e.g. Indonesia and DR Congo) associated with potential mitigation interventions and this should be considered as part of the decision making process. A number of countries have a high mitigation potential but indicators for these countries suggest a weak enabling environment (e.g. Angola, Honduras; Table 4). In these cases, long-term support which also seeks to build governance capabilities is required.

Within the agriculture and forestry sectors in particular, there are potential trade-offs (risks to livelihoods and the environment) associated with mitigation interventions. Following the principles of sustainable intensification or climatesmart agriculture can minimize these costs (Foley et al., 2011; Garnett et al., 2013). Interventions which deliver multiple benefits, in terms of yield increases, mitigation and adaptation components can also offer opportunities to support vulnerable communities where risks such as food insecurity or reliance on agriculture for income are present. There is a need to look beyond the broad interventions which are discussed in this paper, and the growing body of evidence on climate-smart agriculture (FAO, 2013) is providing examples of best practices in specific locations. Further research is also required to consider other risks, for example to biodiversity, which can be impacted by changes to agricultural systems. This systematic framework can be replicated for other scenarios, or at other scales (for example regional and local) to identify priorities for mitigation across sectors in a transparent manner.

\section{The Supplement related to this article is available online at doi:10.5194/bg-12-4809-2015-supplement.}

Author contributions. M. Herold, L. Verchot and S. Carter designed the study; M. Herold, M. C. Rufino and S. Carter developed the methods; K. Neumann provided data; S. Carter performed the analysis; all authors interpreted the results. S. Carter prepared the manuscript with contributions from all co-authors.

Acknowledgements. This research was generously supported by the contributions of the governments of Australia (Grant Agreement \# 46167) and Norway (Grant Agreement \#QZA-10/0468) to the Center for International Forestry Research. This work was carried out as part of the Consultative Group on International Agricultural Research programs on Trees, Forests and Agroforestry (FTA) and Climate Change Agriculture and Food Security (CCAFS). The authors thank Valerio Avitabile and John Stuiver for technical support, and reviewers for their valuable comments on this and a previous version of the manuscript.

Edited by: R. M. Roman Cuesta 


\section{References}

Achard, F., Beuchle, R., Mayaux, P., Stibig, H. J., Bodart, C., Brink, A., Carboni, S., Desclée, B., Donnay, F., Eva, H. D., Lupi, A., Raši, R., Seliger, R. and Simonetti, D.: Determination of tropical deforestation rates and related carbon losses from 1990 to 2010 , Glob. Chang. Biol., 20, 2540-2554, 2014.

Alexandratos, N. and Bruinsma, J.: World Agriculture Towards 2030/2050 The 2012 Revision, Rome, Italy, 147 pp., 2012.

Angelsen, A.: Moving Ahead with REDD Issues, Options and Implications, edited by A. Angelsen, Center for International Forestry Research (CIFOR), Bogor, Indonesia, 156 pp., 2008.

Angelsen, A.: Policies for reduced deforestation and their impact on agricultural production., P. Natl. Acad. Sci. USA, 107, 19639_ 19644, 2010.

Angelsen, A., Brockhaus, M., Sunderlin, W., and Verchot, L.: Analysing REDD+: Challenges and choices, CIFOR, Bogor, Indonesia, 426 pp., 2012.

Baccini, A., Goetz, S. J., Walker, W. S., Laporte, N. T., Sun, M., Sulla-Menashe, D., Hackler, J., Beck, P. S. A., Dubayah, R., Friedl, M. A., Samanta, S., and Houghton, R. A.: Estimated carbon dioxide emissions from tropical deforestation improved by carbon-density maps, Nature Climate Change, 2, 182-185, 2012.

Baede, A., van der Linden, P., and Verbruggen, A.: Annex to IPCC Fourth Assessment Report, Geneva, Switzerland, 76-79, 2007.

Bajzelj, B., Richards, K. S., Allwood, J. M., Smith, P., Dennis, J. S., Curmi, E., and Gilligan, C. A.: Importance of food-demand management for climate mitigation, Nature Climate Change, 4 , 924-929, 2014.

Borlaug, N.: Feeding a Hungry World, Science, 318, 359, 2007.

Burney, J. A., Davis, S. J., and Lobell, D. B.: Greenhouse gas mitigation by agricultural intensification., P. Natl. Acad. Sci. USA, 107, 12052-12057, 2010.

Byerlee, D., Stevenson, J., and Villoria, N.: Does intensification slow crop land expansion or encourage deforestation?, Glob. Food Sec., 3, 92-98, 2014.

Campbell, J. E., Lobell, D. B., Genova, R. C., and Field, C. B.: The global potential of bioenergy on abandoned agriculture lands, Environ. Sci. Technol., 42, 5791-5794, 2008.

Cardona, O., van Aalst, M., Birkmann, J., Fordham, M., McGregor, G., Perez, R., Pulwarty, R. S., Schipper, E. L. F., and Sinh, B. T.: Determinants of Risk?: Exposure and Vulnerability, Cambridge University Press, Cambridge, UK, 65-108, 2012.

Cassman, K. G.: Ecological intensification of cereal production systems: yield potential, soil quality, and precision agriculture, $\mathrm{P}$. Natl. Acad. Sci. USA, 96, 5952-5959, 1999.

Cattaneo, A.: A General Equilibrium Analysis of Technology, Migration and Deforestation in the Brazilian Amazon, 9-90, CABI, Wallingford, UK, 2001.

Cohn, A., Bowman, M., Zilberman, D., and O'Neill, K.: The Viability of Cattle Ranching Intensification in Brazil as a Strategy to Spare Land and Mitigate Greenhouse Gas Emissions, Copenhagen, Denmark, 39 pp., 2011.

Creed, A., Strassburg, B., and Latawiec, A.: Agricultural Expansion and REDD+: An Assessment of the Risks and Considerations to inform REDD+ and Land Use Policy Design, Washington, DC, 6 pp., 2010.

Dalla-Nora, E. L., de Aguiar, A. P. D., Lapola, D. M., and Woltjer, G.: Why have land use change models for the Amazon failed to capture the amount of deforestation over the last decade?, Land Use Policy, 39, 403-411, 2014.

DeFries, R., Herold, M., Verchot, L., Macedo, M. N., and Shimabukuro, Y.: Export-oriented deforestation in Mato Grosso?: harbinger or exception for other tropical forests?, Philos. Trans. R. Soc. Lond. B, 368, 1-8, 2013.

Droogers, P., Seckler, D., and Makin, I.: Estimating the Potential of Rain-fed Agriculture, Colombo, Sri Lanka, 14 pp., 2001.

Duwayri, M., Tran, D. Van, and Nguyen, V. N.: Reflections on yield gaps in rice production: how to narrow the gaps, FAO Regional office for Asia and the Pacific, Rome, Italy, 61 pp., 2000.

Eitelberg, D. a., van Vliet, J., and Verburg, P. H.: A review of global potentially available cropland estimates and their consequences for model-based assessments, Glob. Chang. Biol., 21, 1236-1248, 2015.

ESA: Land Cover State 2010 (2008-2012) 300m v1.1, Paris, France, 2013.

Fader, M., Gerten, D., Krause, M., Lucht, W., and Cramer, W.: Spatial decoupling of agricultural production and consumption: quantifying dependences of countries on food imports due to domestic land and water constraints, Environ. Res. Lett., 8, 1-15, 2013.

FAO: Global Forest Resources Assessment: Main report, FAO Forestry Paper 163, Rome, 340 pp., 2010.

FAO: Climate-Smart Agriculture Sourcebook, Rome, Italy, 557 pp., 2013.

FAO: FAOSTAT glossary, available at: http://faostat.fao.org/site/ 375/default.aspx (last access: 18 March 2015), 2014a

FAO: Food and Agriculture Organisation of the United Nations statisitical database, available at: http://faostat3.fao.org/home/ index.html (last access: 18 March 2015), 2014b.

FAO \& JRC: Global forest land-use change 1990-2005, Rome, Italy, 40 pp., 2012.

Fischer, G., Nachtergaele, F., Prieler, S., Velthuizen, H. T. van, Verelst, L., and Wiberg, D.: GAEZ v3.0., 179 pp., 2008.

Foley, J. A, Ramankutty, N., Brauman, K. A, Cassidy, E. S., Gerber, J. S., Johnston, M., Mueller, N. D., O’Connell, C., Ray, D. K., West, P. C., Balzer, C., Bennett, E. M., Carpenter, S. R., Hill, J., Monfreda, C., Polasky, S., Rockström, J., Sheehan, J., Siebert, S., Tilman, D., and Zaks, D. P. M.: Solutions for a cultivated planet, Nature, 478, 337-342, 2011.

Frieler, K., Levermann, A., Elliott, J., Heinke, J., Arneth, A., Bierkens, M. F. P., Ciais, P., Clark, D. B., Deryng, D., Döll, P., Falloon, P., Fekete, B., F olberth, C., Friend, A. D., Gellhorn, C., Gosling, S. N., Haddeland, I., Khabarov, N., Lomas, M., Masaki, Y., Nishina, K., Neumann, K., Oki, T., Pavlick, R., Ruane, A. C., Schmid, E., Schmitz, C., Stacke, T., Stehfest, E., Tang, Q., Wisser, D., Huber, V., Piontek, F., Warszawski, L., Schewe, J., Lotze-Campen, H., and Schellnhuber, H. J.: A framework for the cross-sectoral integration of multi-model impact projections: land use decisions under climate impacts uncertainties, Earth Syst. Dynam., 6, 447-460, doi:10.5194/esd-6-447-2015, 2015.

Garnett, T.: Climate change and agriculture: Can market governance mechanisms reduce emissions from the food system fairly and effectively?, International Institute for Environment and Development, London, 71 pp., 2012.

Garnett, T., Appleby, M. C., Balmford, A., Bateman, I. J., Benton, T. G., Bloomer, P., Burlingame, B., Dawkins, M., Dolan, L., Fraser, D., Herrero, M., Hoffmann, I., Smith, P., Thornton, P. K., Toul- 
min, C., Vermeulen, S. J., and Godfray, H. C. J.: Sustainable Intensification in Agriculture: Premises and Policies, Science, 341, 33-34, 2013.

Gibbs, H. K., Ruesch, A. S., Achard, F., Clayton, M. K., Holmgren, P., Ramankutty, N., and Foley, J. a: Tropical forests were the primary sources of new agricultural land in the 1980s and 1990s, P. Natl. Acad. Sci. USA, 107, 16732-16737, 2010.

Grieg-Gran, M.: Beyond forestry: why agriculture is key to the success of REDD+, London, UK, 4 pp., 2010.

Gutiérrez-Vélez, V. H., DeFries, R., Pinedo-Vásquez, M., Uriarte, M., Padoch, C., Baethgen, W., Fernandes, K., and Lim, Y.: Highyield oil palm expansion spares land at the expense of forests in the Peruvian Amazon, Environ. Res. Lett., 6, 1-5, 2011.

Hansen, M. C., Potapov, P. V, Moore, R., Hancher, M., Turubanova, S. A., Tyukavina, A., Thau, D., Stehman, S. V, Goetz, S. J., Loveland, T., Kommareddy, A., Egorov, A., Chini, L., Justice, C. O., and Townshend, J.: High-Resolution Global Maps of 21stCentury Forest Cover Change, Science, 342, 850-853, 2013.

Harris, N. L., Brown, S., Hagen, S. C., Saatchi, S. S., Petrova, S., Salas, W., Hansen, M. C., Potapov, P. V., and Lotsch, A.: Baseline map of carbon emissions from deforestation in tropical regions, Science, 336, 1573-1576, 2012.

Hergoualc'h, K. and Verchot, L. V.: Greenhouse gas emission factors for land use and land-use change in Southeast Asian peatlands, Mitig. Adapt. Strateg. Glob. Chang., 19, 789-807, 2013.

Hosonuma, N., Herold, M., De Sy, V., De Fries, R. S., Brockhaus, M., Verchot, L., Angelsen, A., and Romijn, E.: An assessment of deforestation and forest degradation drivers in developing countries, Environ. Res. Lett., 7, 1-12, 2012.

Ickowitz, A., Slayback, D., Asanzi, P., and Nasi, R.: Agriculture and deforestation in the Democratic Republic of the Congo: A synthesis of the current state of knowledge, Bogor, Indonesia, 18 pp., 2015.

IPCC: Technical Summary: Working Group III contribution to the IPCC 5th Assessment Report "Climate Change 2014: Mitigation of Climate Change.”, 99 pp., 2014.

Van Ittersum, M. K., Cassman, K. G., Grassini, P., Wolf, J., Tittonell, P., and Hochman, Z.: Yield gap analysis with local to global relevance - A review, F. Crop. Res., 143, 4-7, 2013.

IUCN UNEP-WCMC: The World Database on Protected Areas (WDPA), Aaailable at: www.protectedplanet.net (last access: 18 March 2015), 2014.

Kaimowitz, D. and Angelsen, A.: Economic Models of Tropical Deforestation A Review, Bogor, Indonesia, 139 pp., 1998.

Kastner, T., Rivas, M. J. I., Koch, W., and Nonhebel, S.: Global changes in diets and the consequences for land requirements for food, P. Natl. Acad. Sci. USA, 109, 6868-6872, 2012.

Kissinger, G., Herold, M., and De Sy, V.: Drivers of Deforestation and Forest Degradation: A Synthesis Report for REDD+ Policymakers, Vancouver, Canada, 12 pp., 2012.

Köthke, M., Schröppel, B., and Elsasser, P.: National REDD + reference levels deduced from the global deforestation curve, For. Policy Econ., 43, 18-28, 2014.

Lambin, E. F., Gibbs, H. K., Ferreira, L., Grau, R., Mayaux, P., Meyfroidt, P., Morton, D. C., Rudel, T. K., Gasparri, I., and Munger, J.: Estimating the world's potentially available cropland using a bottom-up approach, Glob. Environ. Chang., 23, 892901, 2013.

Mbow, C.: Africa's risky gamble, Glob. Chang., June, 20-23, 2010.
Mbow, C.: Examining the deforestation paradox for climate change mitigation in Africa, available at: http://cdkn.org/2014/ 09/examining-deforestation-mitigation-in-africa (last access: 15 July 2015), 2014.

Meyfroidt, P. and Lambin, E. F.: Global Forest Transition: Prospects for an End to Deforestation, Annu. Rev. Environ. Resour., 36, 343-371, 2011.

Minang, P., Bernard, F., van Noordwijk, M., and Kahurani, E.: Agroforestry in REDD+: Opportunities and Challenges, Nairobi, Kenya, 4 pp., 2011.

Mokany, K., Raison, R. J., and Prokushkin, A. S.: Critical analysis of root?: shoot ratios in terrestrial biomes, Glob. Chang. Biol., 12, 84-96, 2006.

Monfreda, C., Ramankutty, N., and Foley, J. A.: Farming the planet: 2. Geographic distribution of crop areas, yields, physiological types, and net primary production in the year 2000, Global Biogeochem. Cy., 22, 1-19, 2008.

Neumann, K., Verburg, P. H., Stehfest, E., and Müller, C.: The yield gap of global grain production: A spatial analysis, Agric. Syst., 103, 316-326, 2010.

Peskett, L. and Todd, K.: Putting REDD+ Safeguards and Safeguard Information Systems Into Practice, 10 pp., 2013.

Romijn, E., Herold, M., Kooistra, L., Murdiyarso, D., and Verchot, L.: Assessing capacities of non-Annex I countries for national forest monitoring in the context of REDD+, Environ. Sci. Policy, 19-20, 33-48, 2012.

Roos, E.: Land husbandry Components and strategy, Rome, Italy, 344 pp., 1996.

Rosenzweig, C., Elliott, J., Deryng, D., Ruane, A. C., Müller, C., Arneth, A., Boote, K. J., Folberth, C., Glotter, M., Khabarov, N., Neumann, K., Piontek, F., Pugh, T. A. M., Schmid, E., Stehfest, E., Yang, H., and Jones, J. W.: Assessing agricultural risks of climate change in the 21 st century in a global gridded crop model intercomparison, P. Natl. Acad. Sci. USA, 111, 3268-73, 2014.

Rudel, T. K., Schneider, L., Uriarte, M., Turner, B. L., DeFries, R., Lawrence, D., Geoghegan, J., Hecht, S., Ickowitz, A., Lambin, E. F., Birkenholtz, T., Baptista, S., and Grau, R.: Agricultural intensification and changes in cultivated areas, 1970-2005, P. Natl. Acad. Sci. USA, 106, 20675-20680, 2009.

Saatchi, S. S., Harris, N. L., Brown, S., Lefsky, M., Mitchard, E. T. a, Salas, W., Zutta, B. R., Buermann, W., Lewis, S. L., Hagen, S., Petrova, S., White, L., Silman, M., and Morel, A.: Benchmark map of forest carbon stocks in tropical regions across three continents, P. Natl. Acad. Sci. USA, 108, 9899-9904, 2011.

Salvini, G., Herold, M., De Sy, V., Kissinger, G., Brockhaus, M., and Skutsch, M.: How countries link REDD+ interventions to drivers in their readiness plans: implications for monitoring systems, Environ. Res. Lett., 9, 1-12, 2014.

Sands, R. D. and Leimbach, M.: Modeling Agriculture and Land Use in an Integrated Framework, Clim. Change, 56, 185-210, 2003.

Santilli, M., Moutinho, P., Schwartzman, S., Nepstad, D., Curran, L., and Nobre, C.: Tropical Deforestation and the Kyoto Protocol, Clim. Change, 71, 267-276, 2005.

Searchinger, T. D., Estes, L., Thornton, P. K., Beringer, T., Notenbaert, A., Rubenstein, D., Heimlich, R., Licker, R., and Herrero, M.: High carbon and biodiversity costs from converting Africa's wet savannahs to cropland, Nature Climate Change, 5, 481-486, 2015. 
Smith, P., Haberl, H., Popp, A., Erb, K.-H., Lauk, C., Harper, R., Tubiello, F. N., de Siqueira Pinto, A., Jafari, M., Sohi, S., Masera, O., Böttcher, H., Berndes, G., Bustamante, M., Ahammad, H., Clark, H., Dong, H., Elsiddig, E. a, Mbow, C., Ravindranath, N. H., Rice, C. W., Robledo Abad, C., Romanovskaya, A., Sperling, F., Herrero, M., House, J. I., and Rose, S.: How much land-based greenhouse gas mitigation can be achieved without compromising food security and environmental goals?, Glob. Chang. Biol., 19, 2285-2302, 2013.

Smith, P., Martino, D., Cai, Z., Gwary, D., Janzen, H., Kumar, P., McCarl, B., Ogle, S., O’Mara, F., Rice, C., Scholes, B., Sirotenko, O., Howden, M., McAllister, T., Pan, G., Romanenkov, V., Schneider, U., Towprayoon, S., Wattenbach, M., and Smith, J.: Greenhouse gas mitigation in agriculture., Philos. Trans. R. Soc. Lond. B. Biol. Sci., 363, 789-813, 2008.

Stevenson, J. R., Villoria, N., Byerlee, D., Kelley, T., and Maredia, M.: Green Revolution research saved an estimated 18 to 27 million hectares from being brought into agricultural production, $\mathrm{P}$. Natl. Acad. Sci. USA, 110, 8363-9368, 2013.

Tubiello, F. N., Salvatore, M., Ferrara, A. F., House, J., Federici, S., Rossi, S., Biancalani, R., Condor Golec, R. D., Jacobs, H., Flammini, A., Prosperi, P., Cardenas-Galindo, P., Schmidhuber, J., Sanz Sanchez, M. J., Srivastava, N., and Smith, P.: The Contribution of Agriculture, Forestry and other Land Use activities to Global Warming, 1990-2012, Glob. Chang. Biol., 21, 26552660, 2015.
UNFCCC: UNFCCC REDD+, available at: http://unfecc.int/ methods/redd/items/7377.php (last access: 18 March 2015), 2013.

West, P. C., Gibbs, H. K., Monfreda, C., Wagner, J., Barford, C. C., Carpenter, S. R., and Foley, J. a: Trading carbon for food: global comparison of carbon stocks vs. crop yields on agricultural land, P. Natl. Acad. Sci. USA, 107, 19645-19648, 2010.

Wilkes, A., Tennigkeit, T., and Solymosi, K.: National integrated mitigation planning in agriculture?: A review paper, Rome, Italy, 53 pp., 2013.

World Bank: The Worldwide Governance Indicators (WGI), available at: www.govindicators.org (last access: 18 March 2015), 2012.

World Bank: Open Data, available at: http://data.worldbank.org/ (last access: 18 March 2015), 2013.

WWF: Selection of terrestrial ecoregions, available at: http://wwf.panda.org/about_our_earth/ecoregions/about/ habitat_types/selecting_terrestrial_ecoregions/ (last access: 18 March 2015), 2013.

Zolkos, S. G., Goetz, S. J., and Dubayah, R.: A meta-analysis of terrestrial aboveground biomass estimation using lidar remote sensing, Remote Sens. Environ., 128, 289-298, 2013. 